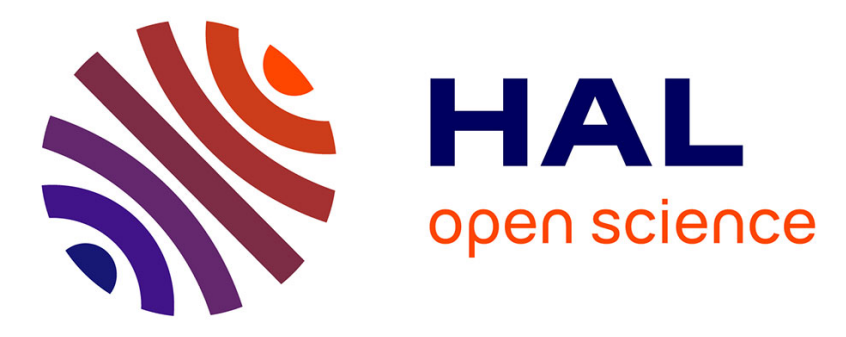

\title{
Jean Hellot and 18th Century Chemistry at the Service of the State
}

\author{
Rémi Franckowiak
}

\section{To cite this version:}

Rémi Franckowiak. Jean Hellot and 18th Century Chemistry at the Service of the State. Raffaele Pisano. A Bridge between Conceptual Frameworks. History of Mechanism and Machine Science, 27, pp.179 - 193, 2015, 978-94-017-9644-6. 10.1007/978-94-017-9645-3_10 . halshs-01906863

\section{HAL Id: halshs-01906863 \\ https://shs.hal.science/halshs-01906863}

Submitted on 27 Oct 2018

HAL is a multi-disciplinary open access archive for the deposit and dissemination of scientific research documents, whether they are published or not. The documents may come from teaching and research institutions in France or abroad, or from public or private research centers.
L'archive ouverte pluridisciplinaire HAL, est destinée au dépôt et à la diffusion de documents scientifiques de niveau recherche, publiés ou non, émanant des établissements d'enseignement et de recherche français ou étrangers, des laboratoires publics ou privés. 


\title{
Chapter 10
}

\section{Jean Hellot and 18th Century Chemistry at the Service of the State}

\author{
Rémi Franckowiak \\ SCité - Sciences, Sociétés, Cultures dans leurs Évolutions, Lille 1 University, \\ Villeneuve-d'Ascq, France \\ e-mail: remi.franckowiak@univ-lille1.fr \\ (C) Springer Science+Business Media Dordrecht 2015 \\ R. Pisano (ed.), A Bridge between Conceptual Frameworks, History of Mechanism and \\ Machine Science 27, DOI 10.1007/978-94-017-9645-3_10
}

\begin{abstract}
The paper proposes a re-evaluation of Jean Hellot's status in relation to the Académie des Sciences but also in relation to the public authorities and to the matter of alchemy. The result will be a reevaluation of the role of the Académie as a unique highly qualified scientific authority in the development of the economy of France in the middle of the eighteenth century, as well as a re-evaluation of alchemical practices perceived from a strictly economic standpoint.
\end{abstract}

Keywords: Jean Hellot • Science academy • Chemistry • Alchemy • State • Economic development - Social scientist status • Eighteenth century

Jean Hellot (1685-1766) is a somewhat forgotten character of the history of science1. Since the end of the 1960's some studies were published highlighting his major role in the development of the dyeing, metallurgical and porcelain work in France, through his essential contribution to the progress of what was called chemical technology2. Indeed since 1752 Hellot was general inspector of the French royal porcelain factory. In 1750 he was the author of a book about the diffusion of the best scientific and technical knowledge of dyeing, $L$ 'art de la teinture des laines et des étoffes de laine en grand et petit teint, avec une instruction sur les déboüillis. In 1750 and 1753 he was also the author of an important two-volume book, based on the reshaped translation of Schlutter's book De la Fonte des mines, des fonderies, \&c., in order to train the workers of French mines, to encourage exploitation of the kingdom's mines and to prepare future directors of mines to exploit most effectively and economically their mines. So Hellot's image established by the historians of science is an image of a chemist who strongly condemned alchemy and was fully involved in the development of craft and factory production during the eighteenth century through his participation as an expert in a lot of committees set up by the Académie Royale des Sciences at the public authorities' request but also through his appointment in a personal capacity as an adviser of the Controller-General of Finances. 
What is proposed in this paper is a re-evaluation of Hellot's status in relation to the Académie des Sciences that he integrated rather late inlife-when he was 50 years old-but also in relation to the public authorities and to the matter of alchemy. The result will be a re-evaluation of the role of the Académie des Sciences as a unique highly qualified scientific authority in the development of the economy of France in the middle of the century, as well as a re-evaluation of the alchemical practices perceived from a strictly economic standpoint. Not only did Hellot advise ministers independently of the ordinary procedures instituted within the Science Academy-not without some tensions with its perpetual secretary - but his alchemical competence could serve the public authorities. Hellot indeed seemed to have fully decided on and accepted a role as a public servant, charged by the State to study all proposals concerning mine exploitation-for which good alchemical knowledge could be sometimes necessary-as well as those concerning the production of several arts and crafts sectors. Thus, thanks to Hellot, the State systematized the use of scientific expertise, standardizing expertise procedures and tending to make official the function of science advisor. The State actually substituted he expertise of Hellot for that of members of the Académie des Sciences with respect to functions which were until then exclusively its own.

It should be noted that Hellot was not so different from the other Academy chemists he knew: Geoffroy, Grosse, Duhamel and Du Fay; however his involvement was deeper. What joined these men together, apart from an obvious friendship, was the combination of the highest level recognition of their scientific activities with alchemical practices and a full submission to the interests of the State.

The permanence of alchemical topics at that time is not surprising. This even allowed, especially since the bankruptcy in 1720 of the economist, then Minister of Finance, John Law's system, the development of deceit that the State wished from now on to reduce in order to re-orientate the financial investments of the kingdom's subjects to the profit of, for example, the exploitation of mining resources technically and legislatively well defined. In a general way, the State had to base a part of its efforts for the development of the economy of France on the competences of the Académie Royale des Sciences' members and, in the case of metallurgy, on that of Jean Hellot and 18th Century Chemistry at the Service of the State its chemists who also had knowledge in the field of alchemy. In this chemists' circle, plenty of time was devoted to these activities; this was especially the case of Jean Hellot. They worked sometimes together, they helped one another, they exchanged manuscripts and quoted one another willingly but they obviously had limited contacts with those who were not so much devoted to the State and the Public: Lemery, Rouelle and Venel among others.

\section{$1 \quad$ Hellot and the Académie des Sciences}

Jean Hellot was short, plump with lively eyes. He was sometimes roguish in his words, but never ironic. He was destined for an ecclesiastic career, but he discovered chemistry quite early through papers and library of his grandfather, whose name was also Jean Hellot and who had translated in 1651 the 1633 Latin book of William Davisson with the title Éléments de la philosophie de l'art du feu ou chimie; so, his interest in chemistry had been already excited by quite old chemistry texts. The perpetual secretary of the Académie Royale des Sciences, Grandjean de Fouchy, in the funeral eulogy that he composed for Hellot's death, remarked, on the 9th April 1766, that Hellot devoted himself to chemistry, "unreservedly", during his youth; this brought him quite early close to Claude-Joseph Geoffroy, who married, in his second marriage, Hellot's niece in 1729. Hellot left afterwards for England in order to meet the scholars of the Royal Society. 
Hellot became also editor in the Gazette de France from 1718. As he was severely struck by the bankruptcy of John Law's financial system, Hellot found himself constrained to continue this job until 1732. Then, according to Grandjean de Fouchy, freed from this constraint as he was,

his friends thought he would claim a position in this Academy \& encouraged him to put himself in for it: we say 'his friends' because he was not one of those who, with false modesty, have confidence in their own merit, \& he, more than anybody else, needed someone to have designs \& ambition for him [...].3

According to the minutes of the Académie's sessions of 16 February 1735, it was the pensionnaires and the associated chemists of the Compagnie who proposed Hellot's candidature,4 namely Geoffroy, Du Fay, Boulduc and Lemery; the election of Hellot was validated on the 2nd of March 1735.5 Almost 4 years later he became directly supernumerary pensionnaire of the Académie - in which he became twice the assistant director (1750 and 1763) and twice also director (1751 and 1764)-and then Fellow of the Royal Society (1740). 6

However, we have to point out that his election had been well-prepared by his friends. In fact we may consider that Hellot's first paper at the Académie had been given before his election. In 1734, Duhamel and Grosse had devoted one third of their dissertation on the liqueur of Frobenius to an extract of a letter that Hellot had recently sent to Duhamel.7 In this letter, we learn that Hellot had worked on this liqueur at least since the year 1731, that was just a little time after Frobenius had sent several little flasks of his liqueur to Etienne-François Geoffroy, as the dissertation revealed anyway.8 The dissertation refers also to the works of Claude-Joseph Geoffroy, his great friend, concerning this liqueur since 1731.

Jean Hellot was already closely related for quite a long time to Claude-Joseph Geoffroy,9 Du Fay, Duhamel du Monceau and Johann Grosse, when he integrated the Académie des Sciences in 1735. These chemists, all of them, shared an obvious interest in alchemical works on metal transmutation. And yet, all these chemists took part, in a privileged manner, in the economic development effort of France initiated in particular by the Regent, Philippe II Duke of Orleans. Philippe, very interested in alchemy, placed directly under his protection, by 1715, the Académie Royale des Sciences which he wanted to make an essential instrument of his projects of reform and re-establishment of the kingdom, especially through the inquiry that he launched from 1716 to 1718 in order to create a national economy to replace the local economies.10 So the Duke of Orleans appears as a key character of the evolution of eighteenth century chemistry: he named academicians people of his entourage related to alchemy, who in their turn proposed candidates at the Académie when a place in the class of chemistry was released. The result was the constitution of a core of alchemical chemists in the Académie who all conformed to the requirement of utility and subordination to the interests of investors looking for scientific and technical competences provided by the Académie des Sciences. The most representative character here was Jean Hellot, practising alchemist and collector of alchemical texts. 11

By the way, the link between science and development of the economy was also clear from the opposite direction, from politics towards science. It should be indeed recalled that the Chancellors of the Exchequer or Intendants of Finances Fagon, Trudaine, Orry, Le Pelletier, Marchault d'Arnouville, Moreau de Séchelles, Bertin, Rouillé were all of them honorary members of the Académie des Sciences, even sometimes vice-presidents and presidents of the Académie.12

After having recalled the State's interest in the Académie, we should go back to the first years of Hellot's academic career. Du Fay, general inspector of dyeing, intendant 
of the Jardin des Plantes and close colleague of Hellot, died on the 16th of July 1739. Hellot was designated his legatee. In spite of his regular attendance, he was absent during the Académie sessions of the 22 and 29 of July. On the 19th of August, he was proposed, as along with two other academicians, for the avail- able post of pensionnaire after the death of Du Fay. Hellot was absent again two more times, on the 2nd and the 5th of September. Only 3 months later, on the 18th of November 1739,13 Hellot was nominated by the king as supernumerary pensionnaire. The exceptionally long delay for the nomination (usually from 4 to 15 days), Hellot's repetitive absences and at the same time the exceptional status of a super- numerary, without having passed through the intermediate grade of the associate, allow us to suppose that during this lapse of time Hellot had been contacted by the State, he had accepted to take over Du Fay's responsibilities and to commit himself entirely to the service of the Controller-General of Finances and of the Intendant of Finances; and during this lapse of time the negotiations with the Académie must have taken place so that he may be proposed a compensation by this exceptional status offering him a quite comfortable position.

Hellot's particular situation, inside and outside the Compagnie, caused tension at least on two occasions. The Académie was very often asked by a Minister or the State services to study several dissertations, books, machines, substances and natural or artificial matters (hundreds of times from 1730 to 1760). A committee was then designated by the director of the Compagnie.14 For instance, on the 7th of January Hellot and Geoffroy were designated commissioners to study Sieur Kemerlin's pewter, as it had been demanded by the minister Maurepas; but contrary to the usual procedure, Hellot refused to hand his report over to the secretary of the Académie, who recorded the event; Hellot wanted to communicate it directly to Maurepas. He finally handed his report over to the secretary Dortous de Mairan a week later.15 It should be noted that a first study for the same pewter had taken place 2 years earlier but in very different conditions, as the commissioners reported. A judgment of the court of the Mint of 23 September 1739 had ordered Kemerlin to reproduce his experiment of purification of the pewter before his lawyer, the general judge of the Mint named Bichon, a clerk of the court, the king's prosecutor and a potter worker known as Charles Julien de Quevanne, appointed as an “expert” by the court; the experiment took place 2 weeks later in Kemerlin's laboratory, Baffroy Street, Faubourg St Antoine. A report was made and completed the next day after some more analyses by Quevanne in his workshop during the night. This report concluded in a few lines only that the examined pewter was pure, so it did not contain other metals nor harmful substances.16 Hellot and Geoffroy were surprised by the rapidity of the test and by the absence of precise information concerning the chemical analysis; they, in contrast, made their test during a period of 3 months before concluding with a very long, thoroughly detailed report. The difference between these two procedures is astonishing: on the first case, it was based on testimony, in a private laboratory, by sworn officers but ignorant of chemistry, with just the opinion of a worker, and on the second one, the procedure took place in the Académie des Sciences, by order of the minister, with specialists in chemistry who took the time to ask, in their turn, the opinion of a worker and to make all the necessary experiments themselves, so as to produce an indisputable report.17

Another tension with the Compagnie broke out in May 1749: by the end of September of the previous year, Hellot had recommended the academician Macquer to reveal nothing to the Académie concerning his discoveries on Prussian blue, thinking that they would interest the State; he also advised him to report them first to the ControllerGeneral of Finances in Fontainebleau. Hellot made on the 26th of March 1749 a public confession, during a session, concerning his initiative, mostly in order to certify the paternity of Macquer on those discoveries, and not really by remorse regarding his 
colleagues (a controversy started then with the abbot François Ménon18); and Macquer read of course his dissertation on this subject only the next April 16 in session, praising in passing Hellot's scientific qualities.19 Macquer, by the way, inherited in his turn Hellot's activities after the latter's death, assuring for the State the continuity of his functions from at least 1730 (with Du Fay) to 1780.

\section{Hellot and the Creation of a True Social Status for the Scientist}

Except for the two mentioned books (which were actually ordered by the Controller-General of Finances) and a dozen or so published dissertations in the Histoire et Mémoires de l'Académie Royale des Sciences,20 most of Hellot's scientific production is only accessible in various handwritten archives: the bulky annual Registres de ProcèsVerbaux de séances de l'Académie Royale des Sciences, the 8552 notes and observations of the Papiers bought by Trudaine from Hellot's widow and today kept in the public library of Caen,21 a thousand or so pages of notes and reports about the mining exploitations in France kept in Mazarine Library,22 and the work documents about porcelain factory. All these documents are well known but they were only superficially studied by the historians of science who preferred to outline an image of Hellot from his public positions of organizer of mine, dyeing and porcelain industries. However, while Hellot entered the service of the State he achieved a status which exceeded his simple status of scholar. He became a man on whom the State relied to carry out some necessary transformations for economic development of the country and to allow the rise of French industry. Hellot embodied the new relations between sciences, technology and politics, taking part in a certain decline of the scientific production of the chemists inside the Académie des Sciences23 because of their increasing investment in many committees ordered by the Compagnie or in different businesses outside of the Académie. The scattered tasks of the academician chemists corresponded to the multiplication of chemical activi ties in the French Society where at that time more and more people not belonging to the Académie had chemical abilities thanks to the strong popularization of chemistry in particular by the means of the many public and private chemistry courses in France.24 In the case of chemistry the Académie des Sciences was not anymore completely able to maintain its monopoly in the field of legitimate scientific authority, in control of scientific production and technical innovation. It seemed to have often followed, administratively, the evolutions.

Hellot was, above all, a servant of the State. Being a member of the Académie des Sciences since 1666-the creation date of this institution-meant sharing pure interests in Science; academicians were supposed to work only for the progress of their discipline and not for personal interests, unlike the common people who were always suspected of looking for profit.25 However from Hellot's time, unselfish scientific work for an academician could mean work for the interests of the State, whose purpose was to use science to rationalize craft and factory practices. So Hellot worked to satisfy such interests. Hellot inaugurated changes in the social representation of the academicianscholar who now had a true function in French Society. No longer being simply isolated authorities in the field of sciences, nor a distinct and separate clan, nor an elite group existing far away from vulgar people and enclosed in their Académie, Hellot and the Academy's chemists now reached out into the social world and acquired a true social status in France. It was the con- sequence of the social recognition by the State of the relevance of their participation in the activities of French Society. 


\section{Hellot, Adviser to the Controller-General of Finances}

Jean Hellot spent most of his time conscientiously studying all the dissertations and requests, on questions of crafts and trades, addressed to Ministers-in particular the Finance Minister - in order to determine their worth, to allot permissions to exploit a mine or to work ores, to evaluate the cost of such exploitations and even the scientific and technical competences of the applicants, as well as to carry out tests, to order inquiries, to get information about mining practices in foreign countries, to intervene in the training of mining engineers, to propose modifications in legislation,26 to improve the security of workers, to supply them with a solidarity fund in case of accident or death, to limit pollution and consumption of wood, to fight against fraud by the manufactured goods or craftsmen productions, and to protect the public health. Hellot's work had one goal: working toward the economic development of France.

From the very first pages of Jean Hellot's manuscript entitled Notes et Observations sur les Mines de France, the expectations of the State for Hellot's work are clear. These pages are about the search for gold spangles accumulated in the sand of the rivers in the Cevennes and the Pyrenees, and correspond to Hellot's reports to the Chancellor from 08/10/1751, 31/05/1752, 03/12/1753, 19/06/1754 and 22/08/1754 about several requests of the abbot de Gua, Jean-Paul de Gua de Malves27 who was at the beginning of the adventure of the famous Encyclopédie ou Dictionnaire raisonnée des sciences, des arts et des métiers. Hellot's function was here-as he said himself-_"to help the Minister to make the wisest decisions". First Jean Hellot received-not necessarily directly-a dissertation of de Gua on the exploitation of gold spangles from rivers. He presented the content of the text to the Chancellor. Then he explained in detail the historical and scientific hypothesis about the topic and went further into de Gua's arguments. Lastly Hellot expressed his favourable opinion:

[...] I believe [...] that we can risk some expense to clear up an assumption which is not unreasonable [...]. I conclude in that way only by supposing that we could make sure first, at little expense, of the reality of the deposit of those gold materials in the pits [...].28

But he warned that the demand from de Gua, who wanted too many workers and too much equipment, should not be fulfilled to the letter: "what, in my opinion, presupposes a very considerable expense". So Hellot proposed to de Gua to work differently by carrying out some tests in a less expensive way, with a kind of drill:

Consequently it will only cost the expenses for the drill and the trip of the author of the project who undoubtedly will be delighted if the Intendant appoints 2 or 3 people, who can certify the success of his operation, to accompany him.29

Hellot recalled what Réaumur had written in his dissertations of the Académie des Sciences about orpailleurs' work and listed what was the most necessary to start the tests:

Here is, as I believe, all that he needs, and 7 to 8 thousand pounds could be enough for the continuation of these experiments until the end of September30.

Afterwards Hellot received, through the Chancellor and a tax farmers-general, another handwritten document with some samples from de Gua's tests. So he carried out some chemical experiments to assess how much gold they contained and he reported his conclusions to the Minister. The amount of gold in the samples was enough to start the exploitation of the spangles.

Hellot's following report was addressed to Trudaine, Intendant of Finances. He summed up the affair and expressed some doubts about de Gua's ability to find partners 
in order to form a company which had to be accepted by the Council of State.31 After a new letter of de Gua sent to the Controller-General of Finances, Hellot proposed to allot him at last the permission to exploit only for 15 months a well- defined area provided that he and his partners compensated the owners of this area for the land and the rivers, secured their exploitation and sent every 3 months to the Council of State a certificate of a public officer about the progress of their work.32 Only after this period, if the Intendant of Languedoc thought that their exploitation was really profitable, could they continue and go further. Then after 5 years, they would pay taxes to the king.

In other affairs reported in his manuscripts, Hellot considered on the contrary that the dissertations he received from the Controller-General of Finances were so ridiculous or suspect that he advised that no answer at all be sent to the applicants.

\section{$4 \quad$ Hellot and Alchemy33}

In the second third of the eighteenth century, the necessity to develop the economy of France was very strong. Nevertheless, alchemical ideas seemed still rather strongly widespread in French Society, which was why Venel made the report in 1753 of an ignorance of what chemistry was and of confusion among people, even educated, between a chemist and a researcher of the Philosophical Stone.34 It became then urgent and important to put order in this confusion: that is to reduce charlatanism in order to protect the State and the public, to divert the people from hazardous alchemical investments towards reliable metallurgical and mining initiatives, while sometimes putting worthy alchemical discoveries to the test. In fact, there were not really at that time two different chemistries, but only one which affected the economic Power and, for this reason, no "useful discovery" was being refused. In a way the State could encourage alchemical research for which the hope was legitimate; alchemy then was especially judged by the measure of its economic profitability.

For example, we can read in Hellot's manuscripts of the following affair.35 In March 1749, a chemistry laboratory was denounced at the Mint. It was suspected of producing false money. The laboratory was established in a large, rather beautiful, house, with a porte cochère, at number 27 of the faubourg St Lazare in Paris. Four- teen furnaces with fire were found. All was seized and soldiers were called to stand guard in front of the house. On Monday, March 31, Mr. Gouault, public prosecutor of the court of the Mint, came to lead Jean Hellot to that address, with the consent of Mr. Rouillé, the Chancellor of the Exchequer, to whom Jean Hellot was answerable. Jean Hellot found there on the right side of the ground floor a chemistry laboratory made up of three rooms. Mr. de Bazinghen, advisor and reporter of the court of the Mint, Mr Renard de Petiton director of the Mint of Paris, and Mr Mayol apothecary opposite to La Madeleine were already on the spot. Hellot then dictated to the clerk of the court of the Mint a description of the furnaces, hermetically closed vessels, utensils, retorts and matters that were there. He concluded his official report by affirming that nothing reprehensible was to be noticed: the people in this laboratory just worked the 'high chemistry', and more precisely they had the aim of extracting "the soul from March and Venus" for the improvement of imperfect metals. So this affair was not a big deal for Hellot, but the court of the Mint wanted to make it important. All the accused people were questioned: Jean-Baptiste Fleuron one of the craftsmen, Jean Thevenot a craftsman in charge of the register of the laboratory, an Italian Joseph Melavi director of the laboratory, Barthélémy Chéron owner of the laboratory and ex-banker imprisoned for five years in the prison of the Abbey of Saint Germain for debts, and his partners: the Knight Roch Eugène de Plessier 
d'Attencourt, Jean Charles Lucquet de Perceville, usher of the King and police chief of the gendarmerie, and finally Mr. Le Gendre d’Armény, brother of Mme Crozat.

The question that actually had to be answered was the following one: Did this alchemical work contravene the privilege granted to Chéron on February 11th, 1738? Because the laboratory was perfectly legal in fact. An authorization in due form had been delivered for the conversion of iron into steel and especially for the production of genuine tin, similar to Cornish tin, but without using tin ores, in other words a production of artificial tin. Hellot did not hide his perplexity about the reason of the issue of such an authorisation because he refuted the idea that it was possible to produce tin starting from other things than tin ores. And saying that all the work carried out in this laboratory remained strictly within the framework of the 1738 authorisation, as Chéron defended himself, could not be a good enough argument because, as Hellot noticed: "this answer in order to divert the idea of an alchemical work is alchemical itself and full of pure gibberish, incomprehensible even for alchemists". And for Hellot it was necessary to denounce the "alleged alchemists". Looking at the 20 letters, on philosophical gold, the universal medicine, the putrefaction of silver, etc., found in the laboratory which Hellot had also to appraise and explain, he showed that this laboratory was actually intended for the preparation of what "the authors of alchemy name Specifics,36 that is operations supposed to make the alchemists rich, but much more slowly than with the Philosopher's stone." And Hellot continued by saying that "In the hands of suspect people, these processes are used to amuse the credulous ones and to allow these suspect people to live at the expense of the latters."

At the beginning, Hellot thought sincerely that Chéron had duped his partners into financing his alchemical research in the hope of all of them becoming rich. However, after having piled up some information, Hellot understood that the Knight d'Attencourt, Le Gendre d'Armény and Perceville, certainly duped by Chéron, duped in their turn other people into giving them money. However, Hellot became more and more disappointed: actually, everybody was implicated in this affair:

- Further to the intervention of the public prosecutor Gouault, the judgment published by the Mint on May 19th, 1749 was not the judgment delivered by the first president of the court of the Mint. Chéron's furnaces, ingot moulds and crucibles were broken but vessels, matters, and utensils were returned to him.

- Around the end of the month, Chéron escaped from prison and left for Germany with the Knight d'Attencourt to live at a princess' expense.

- Perceville boasted that he would open soon another laboratory in a place where he would not be worried.

- Trudaine, Intendant of Finances, said to Hellot that: "It was necessary to let them do it without appearing to know; madmen as they are, these alchemists are able to find sometimes good things etc."

- Then, on Friday, May 31, Bazinghen, advisor of the Mint, "came to Hellot's home in order to be given back the retort full of cooked yellow vitriol which Hellot had taken with him, in order to examine it, the day of the inventory”. Then Bazinghen confessed to him that the retort he returned him had cost him 1200 pounds.

- Finally, the following day, via the clerk, the public prosecutor of the Mint, Gouault, tried to corrupt Hellot. He wanted most probably Hellot not to make waves nor talk around him about this affair. No doubt, Gouault had invested also some money in Chéron's laboratory.

This story is derived from Hellot's handwritten copies of reports and letters during his activities as adviser of several Ministers of the mines of France. There are other such accounts, like Hellot's appraisal, ordered by the Chancellor of the Exchequer himself, of 
an artificial silver production just based on the heating of mercury with very high temperature and strong pressure.37 The appraisal concluded of course that it was a failure but the operation was worth carrying out because, according to Hellot, Wilhelm Homberg would have had a similar idea in one of his dissertations read at the Académie des Sciences.38 Another account? This one about a certain Pillon who would have been in touch with a secret chemistry laboratory at Barrière de St Jacques in Paris and who referred to a charlatan and wine dealer, called Soulatre, in league with some Parisian goldsmiths, and who worked with Madame d'Urfé,39 known for her propensity towards alchemy and especially for huge amounts of money she gave to some adventurers such as Casanova, the Count of Saint German and Cagliostro.

\section{Conclusion}

Hellot's involvement at the service of the State led to systematization of the use of scientific expertise and standardization of expertise procedures. The science advisor to business of the public had now become an almost official position. While the chemist had a recognized function in French Society-a true social status- the Académie des Sciences lost a part of its legitimacy on the matter of science. From now on, the chemist was not completely anymore in possession of the scientific authority because he was belonging to this institution but he could claim it independently.

Moreover, the standardization of the expertise procedures concerned indiscriminately a charcoal mine exploitation in Northern France (Anzin) for example and the production of artificial gold or silver in a discreet Parisian laboratory. In the French Society of the second third of the eighteenth century, alchemy was a still widespread practice in which the State could be interested if it was supposed profitable. At that time a more dangerous practice than chemical deceits was rather a badly-exploited mine. The State-with Hellot's help—-had the will to regulate all craft and factory practices, alchemical as well as mining. Nevertheless it was much more worrying to the State to risk spoiling all its efforts in encouragement to exploit mines by the behaviour of incompetent people, than to let probably erroneous alchemical doctrines be studied and practiced. The necessity to develop the economy of France was very strong and thus it appeared urgent to put the crafts in order, to reduce the number of harmful projects and activities of interest to the State, to divert hazardous in- vestments of swindlers to wellmanaged metallurgical and mining works, while on occasion it could be interesting to put to the test some metal transmutations judged possibly profitable.

\section{Notes}

1 This paper is a work in progress.

2 The expression 'chemical technology' was proposed by Todericiu (1975) Chimie théorique et appliquée au milieu du XVIIIe siècle. Euvre et vie de Jean Hellot (1685-1766), PhD thesis, University of Paris-Sorbonne [handwritten 522 p. and annexes]. It was taken up in Wisniak (2009) Jean Hellot. A pioneer of chemical technology, Revista CENIC Ciencias Químicas 40/2:111-121. About Jean Hellot, see also Thuillier and Birembaut (1966) Une source inédite: les cahiers du chimiste Jean Hellot (1685-1766), Annales. Economies, Sociétés, Civilisations, 21/2:357-364; and the other articles of Todericiu (1976) La bibliothèque d'un savant chimiste et technologue parisien du XVIIIe siècle. Livres et manuscrits de Jean Hellot (1685-1766), Physis. Rivista inter- nazionale di Storia della Scienza Firenze, 18/2:198-216; the same (1976) Correspondance de Jean Hellot, Revue de Synthèse 97/81-82:129; the same (1977) Le traité de chimie inachevé 
de Jean Hellot (1685-1766), Physis. Rivista internazionale di Storia della Scienza Firenze, 19/1-4:355- 375; the same (1983) Les mines du pays de Liège dans les papiers du Savant Français Jean Hellot (1685-1766), Technologia, Histoire des techniques, archéologie industrielle 6/2:61-68; and d'Albis A. (1983) Procédés de fabrication de la porcelaine tendre de Vincennes, d'après les livres de Hellot, Faenza 69/3-4: 202-216.

3 "ses amis le crurent en état de prétendre à une place dans cette Académie, \& l'engagèrent à s'y présenter: nous disons ses amis, car il n'étoit pas de ceux qui, sous une fausse modestie, savent se faire confidence à eux-mêmes de leur propre mérite, \& il avoit besoin plus que personne qu'on se chargeât d'avoir des vues \& de l'ambition pour lui [...]”, Grandjean de Fouchy (1976) Éloge de M. Hellot, Histoire et Mémoires de l'Académie Royale des Sciences, 169.

4 To substitute La Condamine nominated associate. Two other people were actually proposed too: Haber and de la Rivière.

5 See Procès-Verbaux de séances de l'Académie Royale des Sciences (1735), t. 54 , ff. $35 \mathrm{r}$ et $41 \mathrm{r}$.

6 On 23 October 1740, see The record of the Royal Society of London for the promotion of nature knowledge (1940), London, 1940, 406.

7 Duhamel and Grosse (1734) Recherche chimique sur la composition d'une liqueur tres-volatile, connuë sous le nom d'Éther, Histoire et Mémoires de l'Académie Royale des Sciences, 41-54.

8 Grosse, as for him, received from the German chemist Godfrey Hanckwitz, living for long time in London, who left in the Philosophical Transactions (May 1730) a dissertation on the subject.

9 Here is what was written by Monnet A. G., Démonstration de la fausseté des principes des nouveaux chimistes, pour servir de supplément au "traité de la dissolution des métaux, an 6, 360-361: "Hellot: simple homme de lettres d'abord, et rédacteur de la Gazette de France. En fréquentant les Geoffroy, ses parents, et en les voyant opérer dans leur laboratoire, qui étoit alors le rendez-vous de tous ce qu'il y avoit à Paris des savans en chymie, il prit du goût pour cette science, suivit leurs travaux, s'attacha principalement à ceux qui se faisoient sur les minéraux. Il devint essayeur des mines de France, sous les contrôleurs généraux des finances Orry et Trudaine le père, et entra à l'académie des sciences. Il composa un traité des teintures par ordre du gouvernement, en ras- semblant tous les procédés en usage chez les ouvriers, et mit en françois le Traité de la fonte des mines, par Schlutter, qu'avoit traduit de l'allemand [Koenig], directeur des mines de Poulluen en Bretagne, et obtint une pension considérable de l'état.”

10 See Demeulenaere-Douyère and Sturdy (2008) L'enquête du Régent 17161718. Sciences, techniques et politique dans la France pré-industrielle, Éditions Brepols, Turnhout.

11 See Franckowiak R., forthcoming in 2015 in Almagest.

12 But not Herault, the State Counsellor who gave the authorisation of 1738 in favour of Chéron to produce artificial realistic tin, as we will see further in this paper.

13 See respectively the Registres Procès-Verbaux de séances de l'Académie Royale des Sciences (1739), t. 58, ff. 143r, 145r, 213r et 221r.

14 See Hahn (1994) L'Anatomie d'une institution scientifique: l'Académie des sciences de Paris, 1666-1803, (1st English edition in 1969), Paris, Yverdon, Éditions des archives contemporaines.

15 See the Registre des Procès-Verbaux de séances de l'Académie Royale des Sciences (1741), t. 60, 6-8, about this affair which took place between the 6th and the 14th January.

16 See Jean Hellot's manuscript, Notes et observations des mines de France, Bibliothèque Mazarine, Ms. 2756, pp. 133-148. 
17 From the report of Hellot and Geoffroy (registre des Procès Verbaux de séances de l'Académie Royale des Sciences (1741), p. 10): “Nous aurions fort souhaité que le Sr Charles Julien Quevanne, nommé par le Prevost General des Monnoyes et Mareschaussée de France, pour examnier cet étain, eut voulu dire par quels moyens il s'est trouvé en état dans un espace de temps de 7 ou 8 heures, de rapporter à cet officier qu'après plusieurs operations par lui faites sur une plaque d'étain tirée et coulée le jour d'auparavant vers les 8 heures du soir, d'un plus grand bain dans le Laboratoire [on the fringe: "Extrait du Procès Verbal"], du Sr de Kemerlin, que cet étain est privé du cri qui fait connoître l'acide corrosif que l'étain contient ordinairement; qu'il est sans melange d'aucuns metaux ni d'aucune chose nuisible à la santé, ne contenant uniquement que sa propre substance epurées, que par la calcination, dudit étain on n’apperçoit aucun melange de teinture, et que les fleurs en sont d'une blancheur parfaite. La route qu'il a suivie dans son examen, seroit elle aussi sûre qu'elle est courte. Quoi qu'il en soit nous allons donner le détail des experiences que nous avons precedemment annoncées."

18 On this case, see Lehman C. (who nevertheless did not mention Hellot's role in the delay for Macquer's dissertation présentation in the Académie): Lehman (2012) L'art de la teinture à l'Académie royale des sciences au XVIIIe siècle, Methodos [on line], 12|2012, URL: http://metho- dos.revues.org/2874; DOI: 10.4000/methodos.2874.

19 See the Registre of Procès-Verbaux de séances de l'Académie Royale des Sciences (1749), t. 68, pp. 86 and 204-208.

20 1735: “Analise chimique du zinc. Premier mémoire”, pp. 12-31; “Analise chimique du zinc. Second mémoire”, pp. 221-243; 1736: "Conjectures sur la couleur rouge des vapeurs de l'Esprit de Nitre \& de l'Eau-forte”; 1737: "Le phosphore de Kunckel, analyse de l'urine”, pp. 342-378”; 1738: "Sur du Sel de Glauber trouvé dans le Vitriol sans addition de matiére étrangere", pp. 288- 298; 1739: "Sur la liqueur éthérée de M. Frobenius”, pp. 62-83; 1740: "Théorie Chymique de la Teinture des Etoffes”, pp. 126-148; with L. Lemery, C.-L. Geoffroy "Examen du Sel de Pecais”, pp. 361-370; 1741”: “Théorie Chymique de la Teinture des Etoffes. Second mémoire”, pp. 38-71; 1746: with Camus “Sur l'Etalon de l'aune du Bureau des Marchands Merciers de la ville de Paris"; 1756: "Sur l'exploitation des Mines"; 1763: with Tillet and P.-J. Macquer "Mémoire sur les essais des matières d'or et d'argent”, 1-14; with Duhamel and de Montigny "Sur les vapeurs inflammables qui se trouvent dans les Mines, de charbon de terre de Briançon”.

21 Jean Hellot, Ms. Varia 140, Papiers, 9.

22 Jean Hellot, Ms. 2755: Préface de la traduction de Sclutter et Recueil d'indication des mines de France, 188p.; and Ms. 2756: Notes et observations sur les mines de France, 474.

23 The decline in the number of chemical publications of the Académie des Sciences was quite strong in the middle of the century. Whereas the average over the century of the published chemistry dissertations in the Histoire \& Mémoires de l'Académie Royale des Sciences represented around $13 \%$ of the whole of the published dissertations, their number at the end of the 1740's and the beginning of the 1750's fell to a few units a year (before going up actually to $40 \%$ of all the dissertations at the end of the 1770's with the polemical Lavoisier's work); see Halleux et al. (2001), Les publications de l'Académie royale des sciences de Paris (1666-1793), t. 2 (étude statistique et index généraux), Brepols, Turnhout, pp. 24-25.

24 See Perkins (2010) Chemistry Courses, the Parisian Chemical World and the Chemical Revolution, 1770-1790, Ambix, 57/1, 27-47.

25 Heinich (1987) Arts et sciences à l'âge classique, Actes de la recherche en sciences sociales, 66-67, 73. 
26 On the evolution of mining legislation in France and the role played by Hellot, see Birembaut (1964) L'enseignement de la minéralogie et des techniques minières, Enseignement et diffusion des sciences en France au XVIIIe siècle; and Todericiu (1983).

27 See also Condorcet (1786) Éloge de M. L’abbé de Gua, Histoire et Mémoires de l'Académie Royale des Sciences, 63-76.

28 Hellot, Notes, 2. “[...] je crois [...] qu’on peut risquer quelque depense pour s'éclaircir sur une supposition, qui n’est pas déraisonnable [...]. Je ne conclus ainsi qu'en supposant qu'on pourroit s'assurer d'abord à peu de frais de la réalité du dépôt de ces matiéres aurifiques dans les fosses [...]”.

29 Hellot, Notes, 2 “Alors il n'en coutera que les frais de la sonde et les frais du voyage de l'auteur du projet qui sans doute sera charmé que Mr l'Intendant le fasse accompagner par 2 ou 3 personnes qui puissent certifier le succès de son operation”.

30 Hellot, Notes, 3. "Voilà, à ce que je crois, tout ce qu'il lui faut, et 7 à 8 mille livres pourront suf- fire pour une suite de ces experiences jusqu’à la fin septembre”.

31 Hellot, Notes, 4.

32 Hellot, Notes, 5.

33 The topic of alchemy will be tackled here through the reports ordered by the Controller-General of Finances or other Ministers to Hellot, within the framework of his functions of adviser. The personal alchemical interest and practices of Hellot will be the subject of a following paper which will be published in Almagest, 2015.

34 Venel (1753) Chymie, in Diderot D., Le Rond D’Alembert J., Encyclopédie, Dictionnaire raisonné des Sciences, des Arts et des Métiers, t. III, 408. See Rémi Franckowiak (2009) La chimie dans les dictionnaires et encyclopédies au XVIIIe siècle: une incuriosité peu philosophique, Corpus, revue de philosophie, 56, 37-57.

35 Hellot, Notes, pp. 410-415.

36 "Particuliers" in French.

37 Hellot, Notes, pp. 407-410.

38 We note here the specific interventions of Camus, academician of the class of Geometry, and Baron who republished 14 years later Lemery's Course of Chymistry. 39 Hellot, pp. 415-416.

\section{References}

Birembaut A (1964) L’enseignement de la minéralogie et des techniques minières. In: Enseigne- ment et diffusion des sciences en France au XVIIIe siècle. Hermann, Paris Condorcet N (1786) Éloge de M. L’abbé de Gua. Hist Mém l’Acad R Sci 63-76

d'Albis A (1983) Procédés de fabrication de la porcelaine tendre de Vincennes, d'après les livres de Hellot, 69/3-4. Museo internazionale delle ceramiche di Daenza, Faenza, pp 202-216

Demeulenaere-Douyère C, Sturdy DJ (2008) L’enquête du Régent 1716-1718. Sciences, techniques et politique dans la France pré-industrielle. Brepols, Turnhout

Duhamel H-L, Grosse J (1734) Recherche chimique sur la composition d'une liqueur tres-volatile, connuë sous le nom d'Éther. Hist Mém l'Acad R Sci 41-54

Franckowiak R (2009) La chimie dans les dictionnaires et encyclopédies au XVIIIe siècle: une incuriosité peu philosophique. Corpus Rev Philos 56:37-57

Grandjean de Fouchy J-P (1766) Éloge de M. Hellot. Hist Mém l’Acad R Sci 169_ 
Hahn R (1994) L'Anatomie d'une institution scientifique: l'Académie des sciences de Paris, 1666- 1803, (1st English edition in 1969). Éditions des archives contemporaines, Yverdon

Halleux R, Mc Clellan J, Bebariu D, Xhayet G (2001) Les publications de l'Académie royale des sciences de Paris (1666-1793), t. 2 (étude statistique et index généraux). Brepols, Turnhout 67:47-78

Heinich N (1987) Arts et sciences Ã l'âge classique. Actes Rech Sci Soc 66-

Hellot J (1750a) L'art de la teinture des laines et des étoffes de laine en grand et petit teint, avec une instruction sur les déboüillis. Veuve Pissot, Paris

Hellot J (1750b) De la Fonte des mines, des fonderies, \& c Hellot J (1753) De la Fonte des mines, des fonderies, \& c

Hellot J Notes et observations des mines de France. Bibliothèque Mazarine, Paris, p 474. Ms. 2756

Hellot J Préface de la traduction de Sclutter et Recueil d'indication des mines de France. Bibliothèque Mazarine, Paris, p 188. Ms. 2755

Hellot J Papiers, Bibliothèque Municipale de Caen, Mss. Varia 140, vol 9

Lehman C (2012) L'art de la teinture Â l'Académie royale des sciences au XVIIIe siècle, Methodos [on line from 10 April 2012], 12|2012, consulted 21 december 2013 URL: http://methodos.revues.org/2874. doi:10.4000/methodos.2874

Monnet AG (year 6 [1797-1798]), Démonstration de la fausseté des principes des nouveaux chimistes, pour servir de supplément au Traité de la dissolution des métaux

Perkins J (2010) Chemistry courses, the Parisian chemical world and the chemical revolution, 1770-1790. Ambix 57(1):27-47

Procès-Verbaux de séances de l'Académie Royale des Sciences, Archives de l'Académie des Sciences, Mss, 1735, t. 54

Procès-Verbaux de séances de l'Académie Royale des Sciences, Archives de l’Académie des Sciences, Mss, 1739, t. 58

Procès-Verbaux de séances de l'Académie Royale des Sciences, Archives de l'Académie des Sciences, Mss, 1741, t. 60

Procès-Verbaux de séances de l'Académie Royale des Sciences, Archives de l'Académie des Sciences, Mss, 1749, t. 68

The record of the Royal Society of London for the promotion of nature knowledge, The Royal Society, London, 1940

Thuillier G, Birembaut A (1966) Une source inédite: les cahiers du chimiste Jean Hellot (1685-

1766). Ann Econ Soc Civilis 21(2):357-364

Todericiu D (1975) Chimie théorique et appliquée au milieu du XVIIIe siècle. Euvre et vie de Jean Hellot (1685-1766). PhD thesis, University of Paris-Sorbonne [handwritten 522p. and annexes]

Todericiu D (1976a) La bibliothèque d'un savant chimiste et technologue parisien du XVIIIe siècle. Livres et manuscrits de Jean Hellot (1685-1766). Physis Rivista Int Stor Sci Firenze 18(2):198-216

Todericiu D (1976b) Correspondance de Jean Hellot. Rev Synth 97(81-82):129

Todericiu D (1977) Le traité de chimie inachevé de Jean Hellot (1685-1766). Physis Rivista Int Stor Sci Firenze 19(1-4):355-375

Todericiu D (1983) Les mines du pays de Liège dans les papiers du Savant Français Jean Hellot (1685-1766). Technologia: Histoire des techniques, archéologie industrielle 6(2): 61-68

Venel G-F (1753) Chymie. In: Diderot D, Le Rond D’Alembert J (eds) Encyclopédie, Dictionnaire Raisonné des Sciences, des Arts et des Métiers. p 408. t. 3 
Wisniak J (2009) Jean Hellot. A pioneer of chemical technology. Rev CENIC Cienc Quím 40(2):111-121 